\title{
ĐẶC ĐIỂM LÂM SÀNG, CẬN LÂM SÀNG CỦA VIÊM MÀNG NÃO NHIẼ̃M KHUẨN Ở TRẺ SƠ SINH
}

\begin{abstract}
Nguyễn Thị Quỳnh Nga
Đại học Y Hà Nội

TÓM TẮT

Mục tiêu: Mô tả đặc điểm lâm sàng và cận lâm sàng của viêm màng não nhiễm khuẩn (VMNNK) ở trẻ sơ sinh. Đối tượng nghiên cứu: 133 trẻ sơ sinh được chẩn đoán và điều trị VMNNK tại khoa Hôi sức Sơ sinh Bệnh viện Nhi Trung ương từ 01/07/2019 đến 30/06/2020. Phương pháp nghiên cứu: Nghiên cứu mô tả tiến cứu. Kết quả: Trong số 133 bệnh nhân, 32 trẻ sơ sinh được chẩn đoán VMNNK sớm chiếm tỷ lệ $24 \%$. Trẻ đẻ non mắc VMNNK sớm nhiều hơn trẻ đủ tháng. Các triệu chứng lâm sàng bao gồm: thay đổi nhệt độ $(63,1 \%)$, vàng da $(53,3 \%)$ hay gặp ở trẻ đủ tháng; suy hô hấp (60,2\%), thay đổi nhịp tim (60,2\%), bú kém $(95,5 \%)$, bỏ bú $(61,7 \%)$, li bì $(42,8 \%)$ hay gặp ở trẻ non tháng. Giá trị CRP tăng với trung vị là 31,4(81,6) mg/l. Đặc điểm dịch não tủy với số lượng tếbào có trung vị là 78 (49-415) tế bào/mm³, protein là $1,37(0,97-2,27) \mathrm{g} / \mathrm{l}$, glucose là 2,55 (1,75-3,18) mmol/l. 6/133 (4,5\%). Bệnh nhân có kết quả cấy dịch não tủy dương tính. Kết luận: Triệu chứng lâm sàng của VMNNK sơ sinh thường không đặc hiệu và giống bệnh cảnh nhiễm khuẩn huyết. Trẻ sơ sinh có biểu hiện nhiễm trùng cân được nghĩ tới nguyên nhân VMNNK và nên được chọc DNT sớm. Kết quả nuôi cấy DNT đóng vai trò quan trọng trong chẩn đoán bệnh nhưng tỷ lệ dương tính còn thấp.
\end{abstract}

Từ khóa: Viêm màng não nhiễm khuẩn, nhiễm khuẩn sớ sinh, sơ sinh.

\section{ABSTRACT \\ CLINICAL AND LABORATORY FEATURES OF BACTERIAL MENINGITIS IN NEWBORN}

Objectives: To describe clinical and laboratory features of bacterial meningitis in neuborn. Patients and methods: 133 newborns diagnosed with bacterial meningitis at Neonatal Departement - National Hopital of Pediactrics between July 2019 and June 2020. Results: In total 133 newborns, there were 32 babies diagnosed with late-onset barterial meningitis. Preterms babies had more early-onset barterial meningitis than full-term babies. Clinical features included: change in temperature $(63.1 \%)$, jaundice $(53.3 \%)$, which were common in full-term newborn; respiratory distress $(60.2 \%)$, arrhythmia $(60.2 \%)$, poor feeding $(95.5 \%)$, feeding refusal $(61.7 \%)$ lethargy $(42.8 \%)$ happening in premature infants. The CRP value increased with a median of $31.4(81.6) \mathrm{mg} / \mathrm{l}$. Cerebrospinal fluid parameters with the median of 78 leukocytes $/ \mathrm{mm}^{3}$, the median of protein concentration of $1.3 \mathrm{~g} / \mathrm{L}$, the median of glucose level of $2.5 \mathrm{mmol} / \mathrm{L}$. With cerebrospinal fluid culture, we identified 6 pathogens caused neoantal barterial meningitis.

Nhận bài: 15-2-2021; Chấp nhận: 15-4-2021

Người chịu trách nhiệm: Nguyễn Thị Quỳnh Nga

Địa chỉ: Email: ngaquynh2006@gmail.com 
Conclusions: Clinical symptoms of meningitis in neonatal were not specific. Lumbar puncture had important role to diagnose bacterial meningitis in neonatal. The results of cerebrospinal fluid culture play an important role in the diagnosis but the positive rate is still low.

Key words: Neonatal meningitis, neonatal onset sepsis, newborn.

\section{CÁC CHỮ VIẾT TẮT}

$\begin{array}{ll}\text { VMNNK } & \text { Viêm màng não nhiễm khuẩn } \\ \text { DNT } & \text { Dịch não tủy } \\ \text { CRP } & \text { C Protein reactive }\end{array}$

\section{1. ĐẶT VẤN ĐỀ}

Viêm màng não nhiễm khuẩn ở trẻ sơ sinh vẫn là một thách thức trong chuyên ngành sơ sinh với tỷ lệ tử vong và tỷ lệ di chứng còn cao. VMNNK sơ sinh là bệnh lý nhiễm khuẩn màng não cấp tính ở trẻ dưới 28 ngày tuổi. Tỷ lệ trẻ sơ sinh mắc VMNNK ở các nước phát triển ở các nước đang phát triển, tỷ lệ mắc bệnh cao hơn, ở mức $0,8 \%$ - 6,1\%o, với tỷ lệ tử vong lên đến 58\%. [1] VMNNK ở trẻ sơ sinh được phân loại là khởi phát sớm và khởi phát muộn, được xác định bởi sự hiện diện của các dấu hiệu nhiễm trùng và phân lập sinh vật từ dịch não tủy ở thời điểm trước và sau 72 giờ sau sinh. ở các nước phát triển, nguyên nhân hàng đầu gây bệnh là Group B Streptococcus (GBS), chiếm 50\%, nguyên nhân Escherichia coli chiếm 20\%. [2] Tại các nước đang phát triển, vi khuẩn Gram âm là nguyên nhân chính gây bệnh mà phổ biến nhất là Klebsiella và Escherichia.coli gây VMNNK muộn ở sơ sinh. [3] Vi khuẩn Gram âm là nguyên nhân gây tử vong nhiều nhất cũng như để lại di chứng nặng nề nhất. Chẩn đoán VMNNK sơ sinh dựa vào triệu chứng lâm sàng và xét nghiệm dịch não tủy. Cấy dịch não tủy tìm căn nguyên gây bệnh là tiêu chuẩn tốt nhất để chẩn đoán tuy nhiên tỷ lệ dương tính của xét nghiệm này rất thấp. Các số liệu công bố về bệnh lý VMNNK ở trẻ sơ sinh còn ít, vì vậy chúng tôi tiến hành nghiên cứu này với mục tiêu: Mô tả các đặc điểm lâm sàng, cận lâm sàng và xác định một số căn nguyên gây VMNNK ở trẻ sơ sinh.

\section{2. ĐốITƯợNG VÀ PHƯƠNG PHÁP NGHIÊN CỨU}

\section{1. Đối tượng nghiên cứu}

133 trẻ sơ sinh được chẩn đoán và điều trị VMNNK tại khoa Hồi sức Sơ sinh Bệnh viện Nhi Trung ương từ 01/07/2019 đến 30/06/2020.

Trẻ sơ sinh được tính tuổi từ ngày 0 đến < 28 ngày.

\section{Tiêu chuẩn lựa chọn bệnh nhân}

Các bệnh nhân sơ sinh (<28 ngày tuổi) được chẩn đoán VMNNK dựa vào kết quả xét nghiệm dịch não tủy thay đổi về thành phần sinh hóa, tế bào: Protein: $>1 \mathrm{~g} / \mathrm{l}$ và tế bào: $>21 / \mathrm{mm}^{3}$.

\section{Tiêu chuẩn loại trừ}

Trẻ không được làm đầy đủ các xét nghiệm về DNT.

\subsection{Phương pháp nghiên cứu}

Nghiên cứu mô tả, tiến cứu

Cỡ mẫu: Mẫu thuận tiện, tất cả các bệnh nhân đủ tiêu chuẩn chọn mẫu trong một năm từ 01/07/2019 đến 30/06/2020 sẽ được chọn vào nghiên cứu.

Phương pháp thu thập số liệu: Thu thập số liệu, thông tin bệnh nhân theo mẫu bệnh án nghiên cứu:

- Đặc điểm chung của nhóm nghiên cứu: giới tính, tuổi thai, cân nặng lúc sinh, yếu tố nguy cơ của mẹ, các thủ thuật xâm nhập.

- Đặc điểm lâm sàng: thay đổi thân nhiệt, vàng da, triệu chứng thần kinh (li bì, giảm trương lực cơ, co giật, thóp phồng), tiêu hóa (bú kém, bỏ bú), suy hô hấp, thay đổi nhịp tim. 
- Đặc điểm cận lâm sàng: dịch não tủy (tế bào, protein, glucose, nuôi cấy) và CRP máu.

\subsection{Xử lý số liệu}

Sử dụng phần mềm SPSS 26.0 để nhập và xử lý số liệu. Đối với biến định tính: tính tỷ lệ \%. Đối với biến định lượng tính trị số trung bình, trung vị, phương sai, độ lệch chuẩn, tỷ lệ \%.

\subsection{Khía cạnh đạo đức của nghiên cứu}

Nghiên cứu được sự đồng ý của Hội đồng khoa học Trường Đại học Y Hà Nội, Hội đồng đạo đức của Bệnh viện Nhi Trung ương (số 1565/BVNTWVNCSKTE), của lãnh đạo khoa Sơ sinh, Bệnh viện Nhi Trung ương.

\section{KẾT QUẢ}

Trong thời gian từ 01/07/2019 đến 30/06/2020, tại khoa Sơ sinh Bệnh viện Nhi Trung ương chúng tôi thu thập được 133 bệnh nhân VMNNK, trong đó có 81 trẻ trai và 52 trẻ gái, VMNNK sớm là $32 / 133$ chiếm tỷ lệ $24 \%$.

Bảng 1. Đặc điểm chung của nhóm nghiên cứu

\begin{tabular}{|c|c|c|c|}
\hline Đặc điểm chung & $\begin{array}{c}\text { Tổng } \\
(n=133)\end{array}$ & VMNNK sớm $(n=32)$ & VMNNK muộn ( $n=101)$ \\
\hline \multicolumn{4}{|l|}{ "Tuổi thai (tuần, n, \%) } \\
\hline$<37$ & $55(41,3 \%)$ & $19(59,4 \%)$ & $36(35,6 \%)$ \\
\hline$\geq 37$ & $78(58,7 \%)$ & $13(40,6 \%)$ & $65(64,4 \%)$ \\
\hline \multicolumn{4}{|l|}{ *Cân nặng lúc sinh $(n, \%)$} \\
\hline$<2500 \mathrm{~g}$ & $49(36,8 \%)$ & $22(68,8 \%)$ & $27(26,7 \%)$ \\
\hline$\geq 2500 \mathrm{~g}$ & $84(63,2 \%)$ & $10(31,2 \%)$ & $74(73,3 \%)$ \\
\hline \multicolumn{4}{|l|}{ Yếu tố nguy cơ tử mẹ } \\
\hline *Vờ ối > 12 giờ $(n, \%)$ & $21(15,7 \%)$ & $10(31,2 \%)$ & $11(10,9 \%)$ \\
\hline **Chuyển dạ kéo dài $(n, \%)$ & $20(15 \%)$ & $11(34,4 \%)$ & $9(8,9 \%)$ \\
\hline \multicolumn{4}{|l|}{ Thủ thuật can thiệp } \\
\hline *Đặt nội khí quản (n,\%) & $49(36,8 \%)$ & $19(59,4 \%)$ & $30(29,7 \%)$ \\
\hline *Đặt catheter (n,\%) & $49(36,8 \%)$ & $19(59,4 \%)$ & $30(29,7 \%)$ \\
\hline *Thay đổi nhiệt độ (n,\%) & $84(63,1 \%)$ & $10(31,2 \%)$ & $74(73,2 \%)$ \\
\hline *Vàng da (n,\%) & $71(53,3 \%)$ & $7(21,8 \%)$ & $64(63,3 \%)$ \\
\hline *Li bì $(n, \%)$ & $57(42,8 \%)$ & $24(75 \%)$ & $33(32,6 \%)$ \\
\hline Giảm trương lực cơ $(n, \%)$ & $13(9,8 \%)$ & $3(9,3 \%)$ & $10(9,9 \%)$ \\
\hline Co giật $(n, \%)$ & $6(4,5 \%)$ & $2(6,2 \%)$ & $4(3,9 \%)$ \\
\hline Thóp phồng (n,\%) & $29(21,8 \%)$ & $4(12,5 \%)$ & $25(24,7 \%)$ \\
\hline Bú kém (n,\%) & $127(95,5 \%)$ & $31(96,8 \%)$ & 96 (95\%) \\
\hline *Bỏ bú (n,\%) & $82(61,7 \%)$ & $25(78,1 \%)$ & $57(56,4 \%)$ \\
\hline *Suy hô hấp & $80(60,2 \%)$ & $29(90,6 \%)$ & $51(50,5 \%)$ \\
\hline *Thay đổi nhịp tim & $80(60,2 \%)$ & $28(87,5 \%)$ & $52(51,5 \%)$ \\
\hline
\end{tabular}

${ }^{*} p<0,05$ (test $\chi^{2}$ ) ${ }^{* *} p<0,05$ (Fisher exact test)

Nhận xét: Trẻ đẻ non, cân nặng thấp có tỷ lệ mắc VMNNK sớm cao hơn trẻ đủ tháng. Tỷ lệ trẻ có bà mẹ có chuyển dạ kéo dài, vỡ ối sớm mắc VMNNK sớm cao hơn. Các triệu chứng: thay đổi thân nhiệt, vàng da, li bì, bỏ bú hay gặp hơn ở trẻ có VMNNK muộn trong khi suy hô hấp, thay đổi nhịp tim chiếm tỷ lệ cao ở trẻ có VMNNK sớm. 
Bảng 2. Đặc điểm cận lâm sàng

\begin{tabular}{|l|c|c|c|}
\hline & $\begin{array}{c}\text { Tổng } \\
\mathrm{n}=133\end{array}$ & VMNNK sớm (n=32) & VMNNK muộn (n=101) \\
\hline Biến đổi DNT & & & \\
\hline ***Số lượng tế bào/mm3 & $78(49-415)$ & $90(70-632)$ & $68(41-345)$ \\
\hline ***Protein (g/l) & $1,37(0,97-2,27)$ & $1,7(1,17-2,77)$ & $1,2(0,92-1,85)$ \\
\hline ***Glucose (mmol/l) & $2,55(1,75-3,18)$ & $3,1(2,53-4,79)$ & $2,3(1,67-2,89)$ \\
\hline CRP (mg/l) & $31,4(5,4-87,4)$ & $36,9(3,7-120,1)$ & $29,3(6,6-86,4)$ \\
\hline
\end{tabular}

Giá trị được biểu diễn dưới dạng trung vị (tứ phân vị) ***: Mann-Whitney U test

Nhận xét: Các chỉ số xét nghiệm DNT giữa nhóm VMNNK sớm và muộn đều khác biệt có ý nghĩa thống kê.

Bảng 3. Sự biến đổi màu sắc DNT

\begin{tabular}{|l|c|c|c|}
\hline \multicolumn{1}{|c|}{ Màu sắc DNT } & $\begin{array}{c}\text { VMNNK sớm } \\
(\mathrm{n}=32)\end{array}$ & $\begin{array}{c}\text { VMNNK muộn } \\
(\mathrm{n}=101)\end{array}$ & $\begin{array}{c}\text { Tổng } \\
(\mathrm{n}=133)\end{array}$ \\
\hline Trong & $18(56,2)$ & $62(61,4 \%)$ & $80(60,1 \%)$ \\
\hline Vàng & $8(25)$ & $21(20,8 \%)$ & $29(21,8 \%)$ \\
\hline Đục & $6(18,8)$ & $18(17,8 \%)$ & $24(18,1 \%)$ \\
\hline
\end{tabular}

Nhận xét: Màu sắc DNT ít thay đổi, DNT đục gặp 18,1\%.

—Nuôi cấy DNT

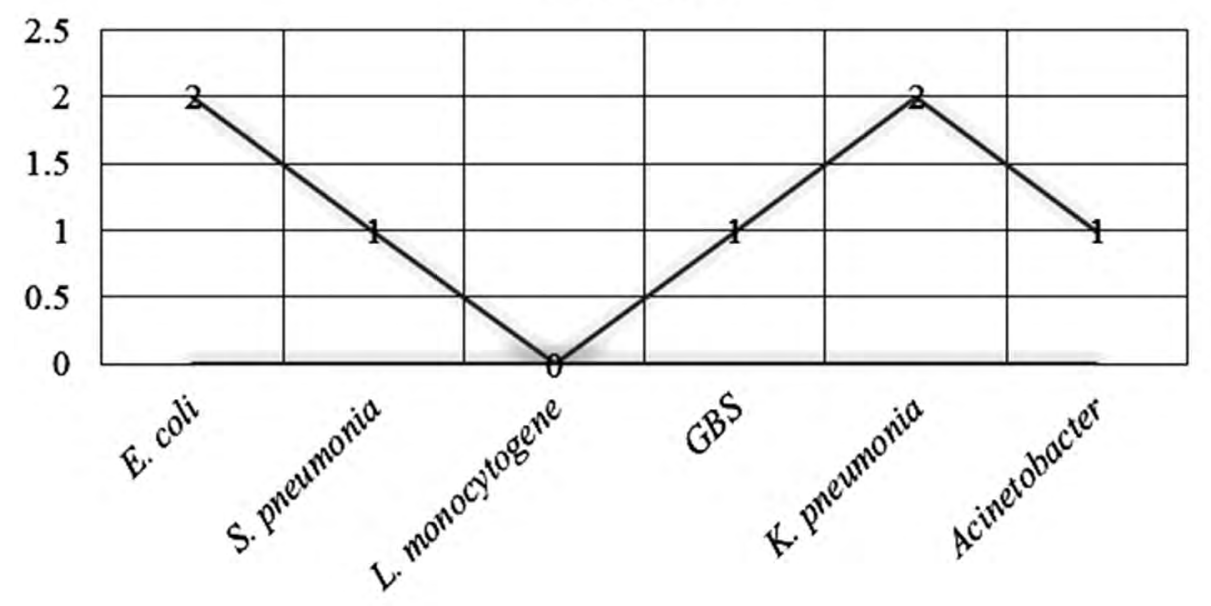

Biểu đồ 1. Kết quả định danh vi khuẩn gây VMNNK

Nhận xét: Có 6/133 (4,5\%) trẻ có kết quả nuôi cấy DNT dương tính, định danh được 5 loại vi khuẩn: Escherichia coli, Streptococcus pneumoniae, Klebsiella pneumoniae, GBS, Acinetobacter. 


\section{BÀN LUÂN}

Chúng tôi nghiên cứu 133 trẻ sơ sinh mắc VMNNK, tỷ lệ nam/ nữ là 1,6/1, VMNNK muộn là chủ yếu, kết quả nghiên cứu này của chúng tôi phù hợp với các tác giả khác: một nghiên cứu đa trung tâm ở phía nam Trung Quốc cho kết quả tuổi mắc bệnh của trẻ là từ 8 ngày tuổi [4], tác giả Aletayeb $\mathrm{MH}$ và cộng sự cho kết quả $58 \%$ trường hợp VMNNK muộn [5].

Bảng 1 cho thấy trẻ đẻ non cân nặng thấp mắc VMNNK sớm nhiều hơn $(p<0,05)$. Kết quả này phù hợp với nhiều nghiên cứu cho thấy VMNNK thường xảy ra ở trẻ có cân nặng thấp và rất thấp, cân nặng khi sinh là một yếu tố nguy cơ quan trọng với việc mắc VMNNK ở trẻ sơ sinh.

Các yếu tố ảnh hưởng trong cuộc đẻ có liên quan rất nhiều đến bệnh lý NKSS trong đó có VMNNK. Những trẻ có mẹ chuyển dạ kéo dài, vỡ ối sớm có tỷ lệ mắc VMNNK sớm cao hơn $(p<0,05)$. Nguy cơ từ những bà mẹ chuyển dạ có nhiễm khuẩn, ối vỡ sớm, ối bẩn làm trẻ sơ sinh bị nhiễm trùng sớm đã được chứng minh trong nhiều nghiên cứu. Những bà mẹ bị nhiễm trùng, những người chăm sóc trẻ vệ sinh tay kém hay nhân viên y tế không thực hiện tốt kiểm soát nhiễm khuẩn trong chăm sóc sơ sinh nằm viện đều là nguồn truyền tác nhân gây VMNNK cho trẻ sơ sinh. [6] Tỷ lệ bệnh theo tình trạng sử dụng các thủ thuật can thiệp trên bệnh nhân, tỷ lệ trẻ phải đặt NKQ, catheter mắc VMNNK sớm cao hơn trẻ không phải sử dụng những thủ thuật này $(p<0,05)$.

Triệu chứng của VMNNK sơ sinh thường kín đáo, không đặc hiệu thường biểu hiện như những nhiễm khuẩn sơ sinh khác dễ làm chẩn đoán nhầm hoặc muộn. Triệu chứng toàn thân hay gặp là sốt hoặc hạ nhiệt độ. [6] Kết quả nghiên cứu chúng tôi thu được (Bảng 1): các triệu chứng toàn thân là thay đổi thân nhiệt gặp chủ yếu ở VMNNK muộn, sự khác biệt có ý nghĩa thống kê với $p<0,05$. Triệu chứng vàng da gặp 71 trường hợp $(53,3 \%)$, chủ yếu ở trẻ mắc VMNNK muộn $(p<0,05)$. Các nghiên cứu khác đều có chung kết quả triệu chứng sốt là triệu chứng toàn thân hay gặp nhất: nhóm hợp tác nghiên cứu về VMNNK sơ sinh tại Trung Quốc cho tỷ lệ 75,1\% [4], Xu M (Thượng Hải) gặp 100\% [7]. Chúng tôi gặp 53,4\% trường hợp có triệu chứng vàng $\mathrm{da}$, triệu chứng này chủ yếu gặp ở trẻ VMNNK muộn, có thể vì trùng hợp với thời điểm ngoài 3 ngày tuổi trẻ bắt đầu có biểu hiện vàng da tăng bilirubin gián tiếp nên triệu chứng này hay gặp. Trong một nghiên cứu từ Thổ Nhĩ Kỳ, hơn một phần ba trẻ sơ sinh bị tăng bilirubin trực tiếp được chứng minh nằm trong bệnh cảnh nhiễm trùng huyết, với vi khuẩn được nuôi cấy định danh phổ biến nhất là E.coli. [8] Các triệu chứng về thần kinh (Bảng 1) hay gặp nhất là li bì (42,8\%). Trong đó triệu chứng li bì gặp nhiều ở nhóm VMNNK sớm (75\%) hơn so với nhóm VMNNK muộn, sự khác biệt này có ý nghĩa thống kê với $p<0,05$. Như vậy triệu chứng li bì đặc hiệu cho chẩn đoán VMNNK sớm, đồng thời cũng là triệu chứng đặc hiệu cho VMNNK ở trẻ đẻ non. Với trẻ đủ tháng triệu chứng thần kinh đặc hiệu là kích thích và thóp phồng tương tự với đặc điểm của trẻ mắc VMNNK muộn. Tác giả Xu M nghiên cứu trên đối tượng sơ sinh đủ tháng VMNNK, thấy triệu chứng co giật, kích thích hay gặp hơn cả và gặp nhiều ở các trường hợp do GBS hơn các căn nguyên khác. [7] Tác giả Kim nhận định triệu chứng thần kinh ở sơ sinh VMNNK là kích thích, co giật và thóp phồng. [9] Một nguyên nhân khiến triệu chứng thóp phồng ít xuất hiện mặc dù là một dấu hiệu giá trị trong chẩn đoán VMNNK sơ sinh là do ở lứa tuổi này các khớp sọ của trẻ đang mở và có thể mở rộng hơn để đáp ứng sự phát triển của não và tăng kích thước vòng đầu theo thời gian, khi đó triệu chứng thóp đầy hay thóp phồng sẽ có thể không nhận định được trên lâm sàng. Rối loạn tiêu hóa bao gồm bỏ bú, bú kém, nôn trớ, tăng dịch dư dạ dày ở trẻ sơ sinh đang nuôi ăn bằng ống thông dạ dày, tiêu chảy và chướng bụng là những triệu chứng thường gặp trong nhiễm khuẩn huyết sơ sinh cũng như VMNNK sơ sinh. Nghiên cứu của chúng tôi (Bảng 1) cho kết quả có $95,4 \%$ ca bệnh có triệu chứng bú kém, $61,6 \%$ trường hợp bỏ bú trong đó 
trẻ VMNNK sớm hay gặp hơn $(p<0,05)$. Hội chứng suy hô hấp, thay đổi nhịp tim (bảng 1 ) đều có tỷ lệ $60,1 \%$, trong đó nhóm bệnh nhân VMNNK sớm hay gặp hơn $(p<0,05)$. Nhóm VMNNK sớm rơi vào bệnh nhân đẻ non, bệnh nhân có bệnh nền nặng, do vậy trẻ thường có các triệu chứng rối loạn nặng về hô hấp và tim mạch.

Nghiên cứu của chúng tôi về xét nghiệm DNT cho kết quả như sau (Bảng 2): tế bào DNT có trung vị là 78 (49-415). Một nghiên cứu ở Hồ Bắc Trung Quốc cho kết quả tế bào DNT tương tự chúng tôi, trung vị là $80 \mathrm{~TB} / \mathrm{mm}^{3}$ (0- 2500). [10] Một nghiên cứu khác ở Trung Quốc, tác giả Tan J cho kết quả, bạch cầu DNT dao động từ 11 đến 17870 TB/mm với trung vị là $80 \mathrm{~TB} / \mathrm{mm}^{3}$, protein DNT thay đổi trong khoảng $0,43-4,75 \mathrm{~g} / \mathrm{l}$ với trung vị là $1,4 \mathrm{~g} / \mathrm{l}$. [11] Tác giả Garges H.P thống kê bạch cầu DNT VMNNK trong nghiên cứu của họ dao động từ 0 đến $15900 \mathrm{~TB} / \mathrm{mm}^{3}$ với trung vị là 477 , đặc biệt có $5 \%$ sơ sinh VMNNK chỉ có $0-1 \mathrm{~TB} / \mathrm{mm}^{3}, 10 \%$ có $\leq 3 \mathrm{~TB} / \mathrm{mm}^{3}$. Chỉ có $18,1 \%$ các trường hợp có DNT đục và chúng tôi không thấy có liên quan giữa màu sắc của DNT với số lượng tế bào DNT.

Để chẩn đoán xác định VMNNK phải có bằng chứng hiện diện vi khuẩn gây bệnh trong dịch não tủy. Tuy nhiên trẻ sơ sinh có thể được tiếp xúc với kháng sinh ngay từ trong bụng mẹ hay được điều trị theo kinh nghiệm khi ra đời trước khi thực hiện chọc dịch não tủy kiểm tra, vì vậy làm kết quả nuôi cấy dịch não tủy âm tính giả. Bằng xét nghiệm nuôi cấy định danh vi khuẩn trong dịch não tủy (Biểu đồ 1 ), nghiên cứu của chúng tôi chỉ thu được tỷ lệ $4,5 \%$ dương tính. Tác giả Xu M nghiên cứu tại Thượng Hải có tỷ lệ cấy dịch não tủy dương tính là $36,5 \%$, tuy nhiên đây là một nghiên cứu kéo dài trong 12 năm. [7] Tác giả Garges HP nghiên cứu trên 9111 trẻ cho kết quả $1 \%$ nuôi cấy dịch não tủy dương tính. [12] Tác giả Wang $Y$ có kết quả nuôi cấy dịch não tủy là $9 \%$. [13] Thực tế cho thấy cấy dịch não tủy tìm căn nguyên là rất khó khăn kéo theo khó khăn trong vấn đề chẩn đoán xác định và lựa chọn phương pháp điều trị thích hợp.

\section{KẾT LUẬN}

Triệu chứng lâm sàng của VMNNK sơ sinh thường không đặc hiệu và giống bệnh cảnh nhiễm khuẩn huyết. Trẻ sơ sinh có biểu hiện nhiễm trùng cần được nghĩ tới nguyên nhân VMNNK và nên được chọc DNT sớm. Kết quả nuôi cấy DNT đóng vai trò quan trọng trong chẩn đoán bệnh nhưng tỷ lệ dương tính còn thấp.

\section{TÀI LIỆU THAM KHẢO}

1. Furyk JS, Swann O, Molyneux E. Systematic review: neonatal meningitis in the developing world. Trop Med Int Health. 2011;16(6):672-679.

2. Klinger, G., Chin, C. N., Beyene, J. \& Perlman, $M$. Predicting the outcome of neonatal bacterial meningitis. Pediatrics 106, 477-482 (2000).

3. Tiskumara, R. et al. Neonatal infections in Asia. Arch Dis Child Fetal Neonatal Ed94, F144148 (2009).

4. Collaborative Study Group for Neonatal Bacterial Meningitis. [A multicenter epidemiological study of neonatal bacterial meningitis in parts of South China]. Zhonghua Er Ke Za Zhi56, 421-428 (2018).

5. Aletayeb, M. H., Ahmad, F. S. \& Masood, D. Eleven-year study of causes of neonatal bacterial meningitis in Ahvaz, Iran. Pediatr Int52, 463-466 (2010).

6. Pong, A. \& Bradley, J. S. Bacterial meningitis and the newborn infant. Infect Dis Clin North Am13, 711-733, viii (1999).

7. Xu, M. et al. Etiology and Clinical Features of Full-Term Neonatal Bacterial Meningitis: A Multicenter Retrospective Cohort Study. Front. Pediatr.7, (2019).

8. Tiker F, Tarcan A, Kilicdag H, Gürakan B. Early onset conjugated hyperbilirubinemia in newborn infants. The Indian Journal of Pediatrics. 2006;73(5):409-412.

9. Kim, K. S. Neonatal bacterial meningitis. NeoReviews16, e535-e543 (2015). 
10. The Collaborative Group For Neonatal Meningitis Study TC, Liu CQ. [Epidemiology of neonatal purulent meningitis in Hebei Province, China: a multicenter study]. Zhongguo Dang Dai Er Ke Za Zhi. 2015;17(5):419-424.

11. Tan, J. et al. Clinical Prognosis in Neonatal Bacterial Meningitis: The Role of Cerebrospinal Fluid Protein. PLoS One10, e0141620 (2015).

12. Garges HP, Moody MA, Cotten CM, et al. Neonatal meningitis: what is the correlation among cerebrospinal fluid cultures, blood cultures, and cerebrospinal fluid parameters? Pediatrics. 2006;117(4):1094-1100.

13. Wang $Y$, Guo G, Wang $H$, et al. Comparative study of bacteriological culture and real-time fluorescence quantitative PCR (RT-PCR) and multiplex PCR-based reverse line blot (mPCR/ RLB) hybridization assay in the diagnosis of bacterial neonatal meningitis. BMC Pediatr. 2014;14:224. 